The Catholic University of America, Columbus School of Law

CUA Law Scholarship Repository

1998

\title{
Terminal Sedation as Palliative Care: Revalidating a Right to a Good Death
}

George P. Smith II

The Catholic University of America, Columbus School of Law

Follow this and additional works at: https://scholarship.law.edu/scholar

Part of the Bioethics and Medical Ethics Commons, and the Palliative Care Commons

\section{Recommended Citation}

George P. Smith, II, Terminal Sedation as Palliative Care: Revalidating a Right to a Good Death, 7 CAMBRIDGE Q. HEALTHCARE ETHICS 382 (1998).

This Article is brought to you for free and open access by the Faculty Scholarship at CUA Law Scholarship Repository. It has been accepted for inclusion in Scholarly Articles and Other Contributions by an authorized administrator of CUA Law Scholarship Repository. For more information, please contact edinger@law.edu. 


\title{
Terminal Sedation as Palliative Care: Revalidating a Right to a Good Death
}

\author{
GEORGE P. SMITH, II
}

\author{
....We are such stuff \\ As dreams are made on; \\ and our life \\ Is rounded with a sleep....
}

William Shakespeare

The Tempest, Act IV, Scene 1

Not everyone finds a "salvific meaning" in suffering. ${ }^{1}$ Indeed, even those who do subscribe to this interpretation recognize the responsibility of each individual to show not only sensitivity and compassion but render assistance to those in distress. ${ }^{2}$ Pharmacologic hypnosis, morphine intoxication, and terminal sedation provide their own type of medical "salvation" to the terminally ill patient suffering unremitting pain. ${ }^{3}$ More and more states are enacting legislation that recognizes this need of the dying to receive relief through regulated administration of controlled substances. ${ }^{4}$ Wider legislative recognition of this need would go far toward allowing physicians, in the exercise of their reasonable medical judgment, to administer a range of narcotics and barbiturates to the terminally ill without fear of legal sanctions. Sadly, social attitudes and governmental concerns about the spread of drug addiction provide an undeniable policy nexus that impedes unduly a rational approach or exception for the treatment of pain experienced by the dying. ${ }^{5}$

\section{Pain Management}

One report has suggested that more than $50 \%$ of patients with terminal cancer have physical suffering during the last days of their life controlled, as such, only by sedation. ${ }^{6}$ Another report shows that $40 \%$ of all dying patients in the United States die in pain. ${ }^{7}$ Recently, the Institute of Medicine found that anywhere from $40 \%$ to $80 \%$ of patients with terminal illness report that their treatment for pain is inadequate and prolongs the very agony of death. ${ }^{8}$

The emancipation principle of palliative care states clearly that no scientific or chemical efforts should be spared to enable dying persons to escape from pain that "shrivels their consciousness" and prevents them from maintaining dignity in their final days. ${ }^{9}$ Indeed, the goal of continually adjusted care demands that those who are hopelessly ill be given whatever medication is needed to control pain. ${ }^{10}$ While there can be little dispute about the validity of this principle, there is a widening gap between what can be done and what in fact is done to implement the emancipation principle. ${ }^{11}$ Stated otherwise, although pain can be managed, the central problem remains how to deal with situations where pain management is merely palliative and the disease symptomatology giving rise to the pain itself continues a malignant progression toward deathresulting in an exceedingly low or even nonexistent quality of life for the 
patient and unendurable and refractory episodes of dyspnea, delirium, myoclonus, vomiting, and intractable pain. ${ }^{12}$

\section{An Alternative or a Continuum of Care}

While it has been argued that palliative care is the principal alternative to euthanasia, others contend palliation and euthanasia are but a continuum of medical treatment. ${ }^{13}$ Indeed, some physicians maintain that providing final assistance for the hopelessly ill upon request is a professional responsibility and sound medical practice as such. ${ }^{14}$ Still others suggest that in specific contexts terminal sedation "is covert physician assisted suicide or euthanasia." 15

The very integrity of acceptance and use of sedating pharmacotherapy is tied inextricably to two principles: informed consent and double effect. Before sedation is prescribed and initiated for control of refractory symptoms or those that include a terminal disease with impending death, all other types of palliative treatment should be exhausted. Additionally, there should be mutual agreement by the patient and his or her family of the need for terminal sedation and a full knowledge of the double and ultimate effect of the actions together with the execution of a valid do-not-resuscitate order. ${ }^{16}$

Others have suggested that intravenous barbiturate administration is a preferable alternative to extended use of narcotics, which always runs a risk of severe toxicity (e.g., depression, constipation, nausea, dysphoria, and drug tolerance). By use of a single hypnotic agent, somnolence or pharmacologic hypnosis may achieve the same sedating effect, thereby dissociating patient consciousness from refractory symptomatologies. ${ }^{17}$ Benzodiazepines may be used as a second drug to alleviate noxious side effects or used simply as singular agents in these circumstances. ${ }^{18}$

More and more, as palliative care management develops a national-if not, indeed, international-praxis, it can be hoped that terminal sedation will in time be understood as but a continuum of proper treatment. Efforts must be undertaken to assure that terminal sedation does not fall into a quagmire of taxonomical confusion. If viewed as an action that validates personal autonomy or self-determination, this type of palliative care will no longer be seen incorrectly as either euthanasia or physician-assisted suicide. Rather, with this reclassification or clarification in terminology will come an understanding of a medically proper way to assure a modicum of dignity at death.

\section{A New Medico-Legal Right}

Although a unanimous United States Supreme Court held in June 1997 that there was no federal or fundamental right to commit suicide or, thus, to have assistance in effecting it, ${ }^{19}$ two concurring opinions would appear to validate legally the medical right to terminal sedation as an efficacious form of palliative treatment for intractable pain. Indeed, Justice Sandra Day O'Connor opined that those individuals suffering from a terminal illness accompanied with great pain may presently -in the states of New York and Washington-obtain whatever level of medication determined professionally by a physician will "alleviate that suffering, even to the point of causing unconsciousness and hastening death." 20 
Justice John Paul Stevens went further in his concurring analysis to probe the full extent of one's liberty interest in defining a personal concept of existence. He concluded that since palliative care cannot alleviate every degree of pain and suffering for all patients, there may be situations in which a competent person could make an informed judgment or "a rational choice for assisted suicide." ${ }^{21}$ Legal approbation was given specifically to the unequivocal AMA endorsement of the policy allowing pain-killing medication for terminally ill patients-up to and including use of terminal sedation-even if death is hastened. ${ }^{22}$

For Justice $\mathrm{O}^{\prime}$ Connor, the central issue in this area of consideration is finding a definition of terminal illness and, similarly, safeguarding the voluntariness of patient decisions that have the effect of hastening death. ${ }^{23}$ Although sound, reasonable judgment will always be the touchstone for a determination of terminality-with each disease etiology shaping this decision-recognition of the validity of the tests for determining medical futility would go far in resolving this conundrum. With this would come, it is to be hoped, an additional realization that wider use of terminal sedation as sound palliative care would provide a more acceptable patient choice for self-determination than recourse to both the idea and practice of assisted suicide or of euthanasia. ${ }^{24}$

\section{Normative Standards of Conduct}

Legislative definitions may be proferred for what is a terminal medical condition, and may include incurable and irreversible conditions that "within reasonable medical judgment" will either cause death "within a reasonable period of time" or merely extend the dying process. ${ }^{25}$ Depending again, of course, upon individual patient profiles and disease etiologies, medical judgment will vary as to when conditions are terminal.

One approach to resolving this quandary is to be found in wider acceptance of the doctrine of medical futility. By utilizing 1 of 5 operative standards under this doctrine, a physician could conclude that a patient's condition is indeed terminal and proceed to search a wide range of palliation optionswith terminal sedation being a first order consideration. Accordingly, in cases where a cure is physiologically impossible, continued treatment is nonbeneficial, a desired or positive benefit is unlikely to be achieved, a particular treatment option (although regarded as plausible) has yet to be validated, or a determination is made that a course of treatment is either quantitatively or qualitatively futile, a physician is freed ethically from pursuing further medical treatment. ${ }^{26}$

\section{AMA Guidelines}

Although a terminal illness may well last months or even years, the actual dying process takes anywhere from a few days to a week or two to complete. ${ }^{27}$ It is through the dying process that one may seek to learn that a good death should be but a complement to a life well lived. ${ }^{28}$

Guidelines for good patient care in end-of-life cases are indispensable to the whole educative process here. Initiating an educational dialogue between healthcare professionals and the public at large on this very topic was commenced at 
the June 1997 meeting of the House of Delegates of the American Medical Association. At this meeting, 8 guidelines entitled "Elements of Quality Care of Patients in the Last Phase of Life" were adopted. ${ }^{29}$ These guidelines, which provide not only for the assurance of opportunities to discuss and plan terminal care but additional assurance that preferences for withholding or withdrawing life-sustaining supports will be honored, underscore the central importance of patient dignity and will surely go far in educating the medical profession to the legitimate fears of the terminally ill. ${ }^{30}$

\section{New Directions}

There is both a moral imperative and a political mandate for national health policies to provide more humane end-of-life care for the dying. ${ }^{31}$ In particular, the extent to which palliative medicine can and should provide a type of quality care insurance for those who are dying appears at last to be within public acceptability, with various palliative care teams in fact becoming more popular in healthcare centers throughout the country. Most normally, such a team is composed of a physician, a nurse, a pharmacist, a social worker, and a chaplain, all acting as basic consultants to those consigned to terminal care. The work of these teams has a salutary effect on broader efforts to show by individualized example that palliative care is not solely about preventing pain for those who are dying, but-as well-seeking to deal forthrightly with a plethora of psychological, social, and spiritual problems confronting the patients and their families. Palliative medicine can, in many cases, fill the void of hopelessness in the lives of the hopelessly ill and thereby lift the veil of despair that has forced a demand for assisted suicide because of the very real fear that there is not quality in end-of-life care. ${ }^{32}$

To those disposed to tendentiousness, the suggestion of a taxonomical change of assisted suicide terminology in order to recognize the right of competent, terminally ill individuals to exercise autonomy or self-determination through use of terminal sedation in palliative management would be viewed as but a shallow ruse. ${ }^{33}$ The process of public education needed to effect a significant change here is admittedly complex. Indeed, society may not be equipped to grasp the full consequences of such an educative dialogue on this topic. It therefore remains the primary responsibility of the medical professionsupported by law - to provide the leadership needed to rethink the standards of humane care for treatment at the end of life. ${ }^{34}$

By accepting and applying standards of medical futility to come to grips with a more uniform approach to and understanding of terminal illness, a ready willingness in turn will be seen to accept the use of terminal sedation as a part of palliative treatment and, thus, part of a more comprehensive right to die with dignity and without intractable pain and suffering. ${ }^{35}$ Indeed, as has been argued, this form of care can be viewed truly as part of a continuum of healthcare to which every individual should be entitled. ${ }^{36}$

With the recent effort undertaken by Justice O'Connor and Justice Stevens in the U.S. Supreme Court, ${ }^{37}$ the nation is now being led in a re-evaluation of the ethical validity, medical propriety, and legal correctness of terminal sedation as a normative standard of humane conduct and palliative treatment at the end of life. 


\section{Notes}

1. Pope John Paul, II. Salvifici Doloria, on the Christian Meaning of Human Suffering [apostolic letter], 11 February 1984. Washington, D.C.: U.S. Catholic Conference, 1996;1-40. See also, Previn MP. Assisted suicide and religion: conflicting conceptions of the sanctity of human life. Geo LJ 1996;84:589-616; Mandziuk P. Easing chronic pain with spiritual resources. Journal of Religion and Health 1993;32:47-54.

2. See note 1, Mandziuk 1993.

3. Stiefel F, Morant R. Morphine intoxication during acute reversible renal insufficiency. Journal of Palliative Care 1991;7:45-9; Greene WR, Davis WH. Titrated intravenus barbiturates in the control of symptoms in patients with termianl cancer. Southern Medical Journal 1991;84:332-6.

4. See also Cal. Bus. \& Prof. Code §2241.5 (West 1994); Fla. Stat. Ann. §458.326 (West 1995); Mo. Ann. Stat. $\S \S 334.105$ et seq. (Vernon 1995); Nev. Rev. Stat. $\S 630.3066$ (1995); N.D. Cent. Code $\S \S 19-03.3-01$ et seq. (1995); Or. Rev. Stat. $\$ \S 677.470$ et seq. (1995); Tex. Rev. Civ. Stat. Ann. 4495c (West 1996); Va. Code Ann. §54.1-3408.1 (Michie 1995).

5. Annas GJ. Reefer madness - the federal response to California's medical-marijuana law. New England Journal of Medicine 1997;337:435-9.

6. Fainsinger R, Miller J, Bruera E, Hanson J, Macheachern T. Symptom control during the last week of life on a palliative care unit. Journal of Palliative Care 1991;7:5-11.

7. Lynn J, Teno JM, Phillips RS, et al. Perceptions by family members of the dying experience of older and seriously ill patients. Annals of Internal Medicine 1997;126;97-106.

8. Approaching Death: Improving Care at the End of Life. Washington, D.C.: National Academy Press, 1997.

9. Roy D. Need they sleep before they die? Journal of Palliative Care 1990;6:3-4.

10. Wanzer SH, Federman DD, Adelstein SJ, et al. The physician's responsibility toward hopelessly ill patients. New England Journal of Medicine 1989;320:844-9.

11. Mount B. A final crescendo of pain? Journal of Palliative Care 1990;6:5-6.

12. See note 11, Mount 1990. See also, Smith GP. Utility and the principle of medical futility: safeguarding autonomy and the prohibition against cruel and unusual punishment. Journal of Contemporary Health Law \& Policy 1996;12:1-39; Zucker MB, Zucker HD. Medical Futility and the Evaluation of Life-Sustaining Interventions. New York: Cambridge University Press, 1997.

13. Ogden R. Palliative care and euthanasia: a continuum of care? Journal of Palliative Care 1994; 10:82-5. In terminal sedation, a physician places a dying patient under general anesthesia and withholds nutrition and hydration. Within a week, the patient dies, commonly, from either dehydration or pneumonia or from respiratory failure or other complications. See West M. Sedation and death. Arizona Republic 1998;March 8:1.

14. See note 10, Wanzer et al. 1989:848.

15. Rousseau P. Terminal sedation in the care of dying patients. Archives of Internal Medicine 1996;15:1785-6. See also, Orentlicher D. The Supreme Court and physician-assisted suicide: rejecting suicide but embracing euthanasia. New England Journal of Medicine 1997;337:1236-8.

16. See note 15, Orentlicher 1997. See also, Craig GM. On withholding nutrition and hydration in the terminally ill: has palliative medicine gone too far? Journal of Medical Ethics 1994;20:139-43.

17. See note 3, Greene, Davis 1991.

18. See note 15, Rousseau 1996; Orentlicher 1997.

19. Washington v. Glucksberg, 65 U.S. Law Wk. 4669 (1997), 117 S. Ct. 2258; Vacco v. Quill, 65 U.S. Law Wk. 4695, 117 S. Ct. 2293 (1997).

20. See note 19, Washington v. Glucksberg, at 4679; Vacco v. Quill, at 4700.

21. See note 19, Washington v. Glucksberg, at 4682; Vacco v. Quill, at 4703. See also, Angell M. The Superme Court and physician-assisted suicide-the ultimate right. New England Journal of Medicine 1997;336:50-3.

22. See note 19, Washington v. Glucksberg, at 4683; Vacco v. Quill, at 4704.

23. See note 19, Washington v. Glucksberg, at 4679; Vacco v. Quill, at 4700.

24. Stolberg SG. Cries of the dying awaken doctors to a new approach. New York Times 1997; June 30:A1. See also note 15, Orentlicher 1997.

25. See Rev. Code Wash. Ann. §70.122.020(9) (West 1996-97).

26. See note 12, Smith 1996:6. See also Leplege A, Hunt S. The problem of quality of life in medicine. JAMA 1997;278:47-50; Kuhse H, Singer P. Prolonging dying is the same as prolonging dying. Journal of Medical Ethics 1991;17:305-6.

27. Trafford A. The act of dying, the art of living. Washington Post 1997;July 1, Health Sec.:6. See also Lynn J, Harrell FE, Cohn F, Harrel MB, Dawson N, Wu AW. Defining the terminally ill: 


\section{Terminal Sedation as Palliative Care}

insights from SUPPORT. Duquesne Law Review 1996;35:311-36; McGivney WT, Crooks GM. The care of patients with severe chronic pain in terminal illness. JAMA 1984;251:1182-8.

28. See note 27, Lynn et al. 1996. See also, Hardwig J. Is there a duty to die? Hastings Center Report 1997;27(2):32-42; Nuland SB, How We Die: Reflections on Life's Final Chapter. New Haven: Yale University Press, 1994.

29. Woolley W. AMA issues bill of rights for dying. The Detroit News 1997; June 23:A1.

30. See note 29, Woolley 1997. See also Doctors design rules for care for the dying. New York Times 1997; June 23:A12.

31. Sulmasy D, Lynn J. End of life care. JAMA 1997;277:1854-5. See also Cassell E. The nature of suffering and the goals of medicine. New England Journal of Medicine 1982;306:639-45.

32. See note 24, Stolberg 1997.

33. Smith GP. All's well that ends well: toward a policy of assisted rational suicide or merely enlightened self-determination? University of California Davis Law Review 1989;22:275-419.

34. Quill TE. Death and dignity - a case of individualized decision making. New England Journal of Medicine 1991;324:691-4. See also Cassell E. The Nature of Suffering and the Goals of Medicine. New York: Oxford University Press, 1991.

35. See note 4. See also, Appropriate management of pain [symposium]. Journal of Law, Medicine $\mathcal{E}$ Ethics 1996;24:285-359.

36. See note 13, Ogden 1994; West 1998. See also Quill TE, Cassel CK, Meier DE. Care of the hopelessly ill-proposed clinical criteria for assisted suicide. New England Journal of Medicine 1992;327:1380-4.

37. See notes 19 and 20. 